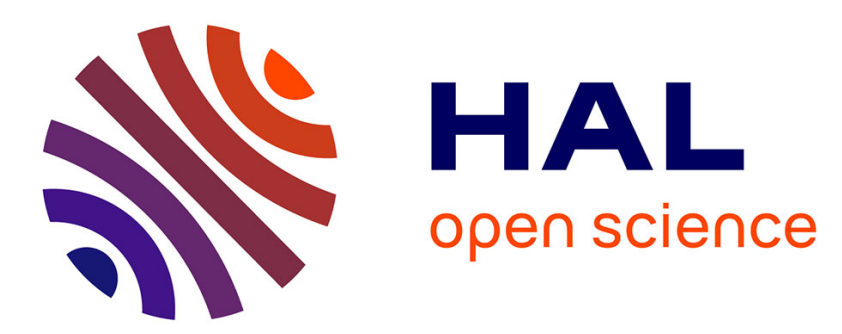

\title{
The Protohistoric sword from Le Gué-de-Velluire (Vendée, France): a pasticcio's history unveiled by archaeometrical research
}

Léonard Dumont, Virginie Dupuy, Théophane Nicolas, Charlène Pelé-Meziani, Guy de Mulder

\section{To cite this version:}

Léonard Dumont, Virginie Dupuy, Théophane Nicolas, Charlène Pelé-Meziani, Guy de Mulder. The Protohistoric sword from Le Gué-de-Velluire (Vendée, France): a pasticcio's history unveiled by archaeometrical research. Journal of Archaeological Science: Reports, 2020, 34 (A), pp.102645. 10.1016/j.jasrep.2020.102645 . hal-02991508

\section{HAL Id: hal-02991508 https://u-bourgogne.hal.science/hal-02991508}

Submitted on 6 Nov 2020

HAL is a multi-disciplinary open access archive for the deposit and dissemination of scientific research documents, whether they are published or not. The documents may come from teaching and research institutions in France or abroad, or from public or private research centers.
L'archive ouverte pluridisciplinaire HAL, est destinée au dépôt et à la diffusion de documents scientifiques de niveau recherche, publiés ou non, émanant des établissements d'enseignement et de recherche français ou étrangers, des laboratoires publics ou privés. 


\section{The Protohistoric sword from Le Gué-de-Velluire (Vendée, France): a pasticcio's history unveiled by archaeometrical research}

Léonard Dumont, $\mathrm{PhD}$ Candidate

Ghent University, Department of Archaeology, Sint-Pietersnieuwstraat 35, 9000 Gent (Belgique)

Université de Bourgogne-Franche-Comté, UMR 6298 ARTEHIS, 6 Boulevard Gabriel, 21000 Dijon

leonard.dumont@ugent.be

Virginie Dupuy, Curator

Musée Dobrée, Grand Patrimoine de Loire-Atlantique, 3 quai de Ceineray, CS 94109, 44041 Nantes Cedex 01

virginie.dupuy@1oire-atlantique.fr

Théophane Nicolas, Ceramics specialist

Inrap Grand Ouest, 37 rue du Bignon, 35577 Cesson-Sévigné

theophane.nicolas@inrap.fr

Charlène Pelé-Meziani, Research engineer

Laboratoire Arc'Antique, Grand Patrimoine Loire-Atlantique, 26 Rue de la Haute Forêt, 44300 Nantes charlene.pele-meziani@loire-atlantique.fr

Guy De Mulder, Associate professor

Ghent University, Department of Archaeology, Sint-Pietersnieuwstraat 35, 9000 Gent (Belgique)

guy.demulder@ugent.be

Abstract: The Gué-de-Velluire sword (Vendée, France) is part of the Rochebrune collection collected during the $19^{\text {th }}$ and the $20^{\text {th }}$ centuries and now preserved in the Dobrée Museum in Nantes (LoireAtlantique, France). The unusual shape of its hilt, its uncorroded rivets and the rather uncommon combination of a bronze grip with an iron blade made this sword an exceptional object. It has been depicted in a large number of papers since the $20^{\text {th }}$ century, but the question of its authenticity has hardly ever been tackled. New analyses performed with the support of the Dobrée Museum, the Arc'Antique laboratory and Ghent University delivered new data enabling us to discuss this delicate question. First, a CT-scan of the sword was performed by the BCRX company (Mordelles, Ille-et-Vilaine, France), offering the opportunity to visualise the inner structure of the hilt and especially the way it is fixed to the iron blade. Secondly, X-Ray Fluorescence analyses were performed by the Arc'Antique laboratory (Nantes, Loire-Atlantique, France) to determine the composition of the different parts of the sword (hilt, rivets and blade). Comparing the results of both analyses with Rochebrune's archives allowed us to assert this weapon is a fake, most likely consisting of two authentic archaeological artefacts, and to reconstruct its production process, shedding light on early $20^{\text {th }}$ century collector's practices.

Keywords: Computed tomography, Pasticcio, Protohistory, Sword, X-Ray Fluorescence spectroscopy

\section{Introduction}


The protohistoric sword supposedly discovered at Le Gué-de-Velluire (Vendée, France; Figure 1) is said to be found by a fisherman in the early $20^{\text {th }}$ century in the Vendée river (Mortillet, 1913). Initially bought by the count Raoul de Rochebrune (1849-1924), who owned a large collection of archaeological artefacts, shortly after 1900, it was then given to the Dobrée Museum (Nantes, Loire-Atlantique, France) in 1930 where it is still preserved today under the inventory number 930.1 .194 . The sword is $74.6 \mathrm{~cm}$ long. It consists of a $12.9 \mathrm{~cm}$ long bronze hilt formed by a rounded guard with a U-shaped notch in its centre, a thin grip with narrow shafts on each side and finally a $9.5 \mathrm{~cm}$ large curved pommel decorated with triangles and motives resembling handles around the central spine. Five rivets are visible on the hilt surface: two on the guard on each side of the notch and three on the grip, where the ones at the bottom and at the top are completed with bronze rings forming discs with a diameter about $1 \mathrm{~cm}$. The $63.7 \mathrm{~cm}$ iron blade is $4.0 \mathrm{~cm}$ wide and $0.6 \mathrm{~cm}$ thick with a rhomboidal section completed by a thin central bulge framed by two thin grooves.

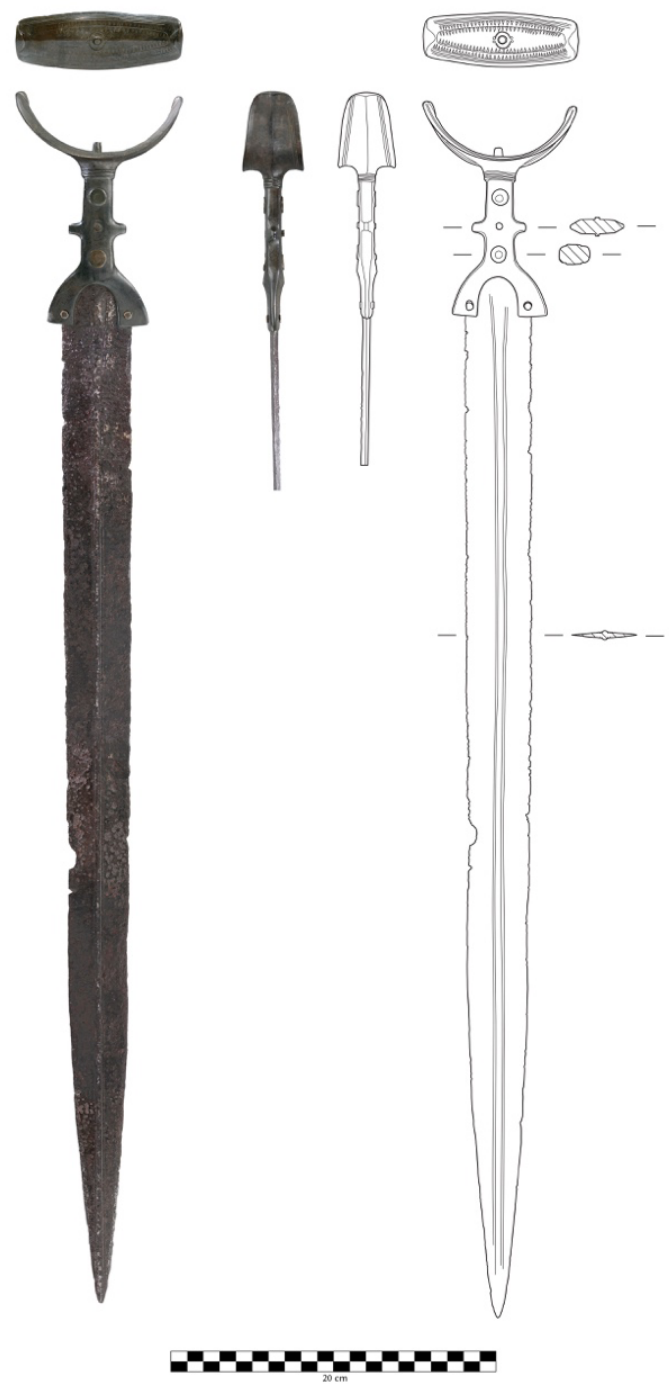

Figure 1: The "Gué-de-Velluire" sword (Vendée, France), Dobrée Museum (Nantes, France), 930.1.194. (C) L. Dumont. 
The study of the Gué-de-Velluire sword takes place within the framework of a joint PhD between the University of Burgundy (Dijon, France) and Ghent University (Belgium) about Bronze Age solid-hilted swords in western Europe. The production techniques being the middlepoint of this study, the Gué-deVelluire sword was CT scanned in order to study how the hilt was made and fixed to the blade. Doubts were raised following this research concerning the authenticity of the artefact, pushing us to perform further analyses on the composition of the different elements the sword is made of using portable X-Ray Fluorescence Spectroscopy (pXRF).

Therefore, this article aims at discussing the authenticity of the Gué-de-Velluire sword through the lens of archaeometric analyses. This is an important question considering the specific position of this sword in the archaeological literature. It is often mentioned and represented for its singular shape (Coutil 1928, 58), to highlight the relations between western France and Scandinavia (Halbert 1954; Müller-Karpe 1961, pl. 44 A) or as one of the oldest iron objects in France (Gomez, Mohen 1981, 54; Pautreau 1984, 243; Milcent 2004, 51, 101; Gomez de Soto, Kerouanton 2009, 505) or even in Europe (Miketta 2017a, 163; Miketta 2017b, 265), without questioning its authenticity.

We will here demonstrate, using archive documents and archaeometric analyses, that the Gué-deVelluire sword is actually a modern chimera created by combining two archaeological artefacts from two different periods, that were originally not designed to be used together. CT-scans and XRF analyses enabled us, together with the documents from the archive about this sword, to reconstitute a part of this object's biography by documenting its transformation between the moment it was acquired by the count de Rochebrune in 1904 and its actual state.

\section{The Rochebrune collection in Dobrée Museum (Nantes, France)}

\subsection{The origins of the collection}

Six years after his death, the count Raoul de Rochebrune's weapons and enamel bronze panels collection was given to the Dobrée Muséum in Nantes (Loire-Atlantique, France) in 1930. The 1024 objects from this collection only represent a small portion of this Vendean aristocrat's extensive personal collection, but it is certainly the most prestigious, recognized as soon as the beginning of the $20^{\text {th }}$ century as one of the richest sets of ancient weapons of France, if not in Europe.

Born in 1848 in Fontenay-le-Comte (Vendée, France), Raoul de Rochebrune dedicated all his life at enhancing and completing his collection of art objects and archaeological artefacts that he inherited from his father, Octave de Rochebrune (1824-1900). He gathered around him at the beginning of the 1890's a vast network of collectors, art dealers, museum curators and other specialists, both at the local and the national scales, who he consulted on a regular basis to buy or authenticate objects he was interested in. He was also paying close attention to the scientific and social recognition this activity could provide him, so much that he studied, described, photographed and set up the exhibition of the objects which he 
owned, following his father footsteps who himself engraved the 400 weapons composing his own collection (Fillon, Rochebrune 1863; Rochebrune 1880).

\subsection{Inconsistencies around the Gué-de-Velluire sword}

But both Rochebrune, father and son, also went beyond archaeological research. Technological observations and archaeometric analyses recently performed on several objects of the collection enabled to determine numerous restorations, re-assemblies and manipulations attributed to the Contemporary period (Parpoil 2007; Barthet 2012). This strengthens the doubts, that have been previously mentioned, for example by Émile Espérandien about the Roman grave from Jard-sur-Mer (Vendée, France), found by Raoul de Rochebrune in 1878 and published as soon as 1879 (Espérandieu 1888). Discussions began about these manipulations and possible forgeries, without having the capacity to identify those who were responsible for it (middlemen before the acquisition, the Rochebrune father or son, Benjamin Fillon etc.?) or their underlying aims (embellishment, clean-up, falsification?). Raoul de Rochebrune's personal correspondence, now preserved in the archives of the Dobrée Museum which were acquired in 1998, suggest that the latter "rehabilitated" and reassembled different kind of objects, like other collectors at this period ${ }^{1}$. Some notes also highlight inconsistencies in the provenances and the way of acquisition.

This is the case for the sword said to be from Le Gué-de-Velluire. The manuscript booklet written around the years 1910 is the original version of the future printed catalogue of the collection (Rochebrune 1917) and is giving us Rochebrune's first comment on this object apparently bought in 1904:

"E. Wonderful Gallic sword hilt adorned with grooves in the shape of triangles casted in one piece with antennae, protruding spikes and buttons; remarkable fabrication, an admirable fine and polished green patina. End of the Bronze Age, ca. 900 BC. I saw it with the abbé Breuil at Bachereau in 1903. He was selling it for 1200 francs. He did not want to give it to me for 1000 francs. The abbé Breuil, seeing this extraordinary piece, was pushing me to take it; I offered him 1100 francs; he answered me it is sold. The next year, 1904, Dazzi presented it to me. I buy it for 650 francs. It was sold to Daguerre who wanted something else and resold it." 2

\footnotetext{
1 - Lettre from Jean-Jacques Reubell to Raoul de Rochebrune dated from the $14^{\text {th }}$ of June 1910: “My dear Friend, this is all I can do; the dagger was too cleaned-up, [...] and unless using drastic means requiring time and on which we cannot always rely on, we will have to let it in that state; it looks less like a new nail but in a few days we can recover the patina of several centuries". Private archives on the Dobrée Museum acquired in 1998 (box A).

2 - Raoul de Rochebrune, Catalogue des armes diverses réunies au château de Terre-Neuve, handwritten booklet with photographic reproductions, ca. 1910. Private archives on the Dobrée Museum acquired in 1998 (box D).
} 
The photo associated with the comment leaves no doubt on the identity of the object with caption $\mathrm{E}$ (Figure 2). It however raises questions because the blade fragment on which the hilt is fixed shows characteristic features of copper alloys. It cannot be compared to the complete iron blade on which the hilt is now mounted.

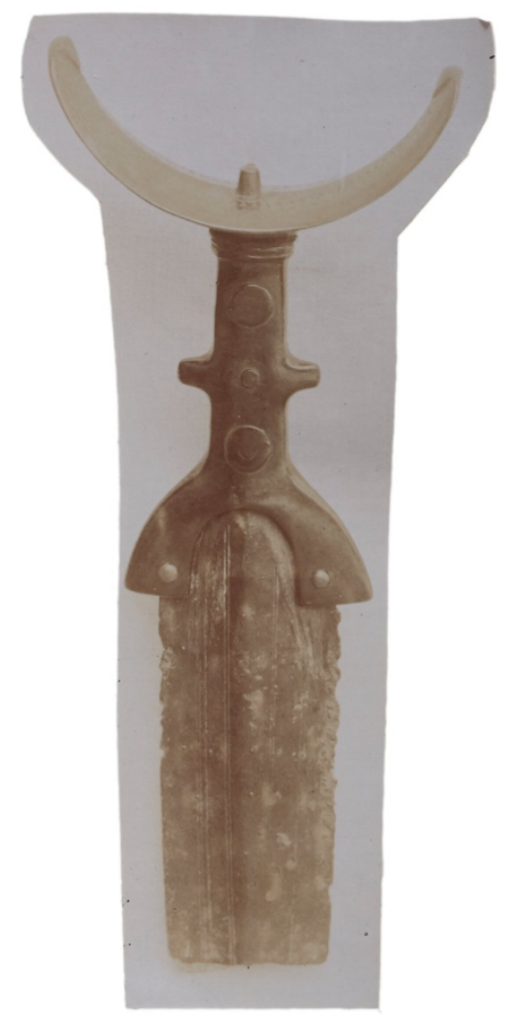

Figure 2: Photograph of the sword in Raoul de Rochebrune's archives. The blade, probably made in a copper-based alloy, is different from the current iron one. (C) Grand Patrimoine de Loire-Atlantique, Dobrée Museum.

Catherine Parpoil was the first to note the contradictions between Rochebrune's comment and the one made a few years later in the article by Mortillet (1913) and then in the catalogue of 1917 (Parpoil 2007, vol. 5, 26-27) : "Later equipped with a blade, this piece become a sword to which A. de Mortillet consecrated no less than 6 pages: this description will then be used in considerable detail by R. de R. in the 1917 printed catalogue". One of the key elements in the changing interpretation of this sword, from a fake to a real archaeological artefact, concerns its provenance. According to Mortillet it would have been discovered "in the municipality of Gué-de-Velluire [...]. Found about ten years ago by a fisherman, it was sold to a collector from the region [...]. It is only after his death that his widow agreed in selling it to Mr. de Rochebrune" (Mortillet 1913, 275). The perspective given by these two stories leaves us sceptical and makes the discovery site of Le Gué-de-Velluire rather hypothetic. It is important to emphasise that it is in Le Gué-de-Velluire Octave de Rochebrune and Benjamin Fillon realised the most important part of their "archaeological excavations" in the middle of the $19^{\text {th }}$ century. Among the 
weapons from the Rochebrune collection, about 80 are said to come from this municipality: "Le Guéde-Velluire is the place where we made the most abundant and precious discoveries. But which causes may have produced this concentration of weapons from such different periods? These causes are revealed to us, at least for the period after Philippe de Valois's reign, by written documents in which many combats at that place are mentioned" (Fillon, Rochebrune 1863, chap. XXXVI, 4). Besides being an important emotional archaeological site for Octave de Rochebrune, le Gué-de-Velluire also had a special value for his son (Rochebrune 1917, 80, no 19). After the congratulations received following the acquisition of the Salorges sword (Loire-Atlantique, France) in 1908 (Mortillet 1909, 230; Rochebrune 1917, 73), the collector probably wanted to make again an impression by presenting to the scientific and collectors communities the Gué-de-Velluire sword, proof of the exceptional historical wealth of the Vendean territory where he himself came from: "[...] all these weapons were found in our rivers from the Poitou, Vendée and Loire-Atlantique; they never belonged to no other amateur. The lord, the knight or the warrior who owned them lost them as a result of death or wounds, they were sent back to us from their hands in a manner of speaking, these are thus sure and often original documents about the history of weapons" (Rochebrune 1911, 154).

The contradictions between the information published by R. de Rochebrune and A. de Mortillet and the old documents connected to this sword make us cautious about its provenance and demonstrate that its actual state, a combination of a bronze hilt and an iron blade, is different from its state when it was bought in 1904. In order to determine how the sword was customized and how the blade was replaced, several methods were set up.

\section{Methods}

\subsection{Computed tomography (CT-scan)}

The CT scanner is a Siemens SOMATOM Sensation 16. It is owned by the French company B.C.R.X. which provides services and expertise on X-Ray images and associated tools. The three-dimensional explorations were performed through two acquisitions and 2D/3D images post-processing. The acquisitions were a topogram for positioning the slices to be realized and a helix scan. The only differences were in $\mathrm{kV}$ and $\mathrm{mAs}$ values, and in the resolution of the cutting map (XY) which depends of the field of view, the matrix of the $2 \mathrm{D}$ slice images being constant ( $512 \times 512$ pixels) on the scanner (Table 1). The scan generates a dataset under DICOM format (Mustra et al. 2008). The data generated during the CT scan were processed with the open-source software Horos (horosproject.org), an image processing application for Mac dedicated to DICOM images, under free software license. Many postprocessing functionalities of Horos were used in the current work, the $3 \mathrm{D}$ volume rendering or $3 \mathrm{D}$ surface rendering and maximum intensity projection (MIP). 


\begin{tabular}{|c|c|c|c|c|c|}
\hline Sword & KV & mAs & Collimation & $\begin{array}{c}\text { Pitch } \\
\text { Quad }\end{array}$ & $\begin{array}{c}\text { Exposure } \\
\text { time }\end{array}$ \\
\hline Handle & 140 & 300 & $156,5 x 0.8 m m$ & 0,45 & $43.42 \mathrm{~s}$ \\
\hline $\begin{array}{c}\text { Handle + blade } \\
\text { 1 mm }\end{array}$ & 140 & 200 & $769 x 0.8$ & 1 & $96.19 \mathrm{~s}$ \\
\hline Handle end & 140 & 300 & $62 \times 0.8$ & 0.45 & $17.17 \mathrm{~s}$ \\
\hline
\end{tabular}

Table 1: CT acquisition parameters

Computed Tomography contributes to the analysis of the "chaine opératoire" of artefacts, especially in bronze or iron. It provides a complete visual of the artefact its structure thus accessing pertinent information for its technological study, which differs from a more superficial analysis restricted to the study of the object and the surface marks linked to its manufacture (Mödlinger 2008; Stelzner 2016; Dumont et al. 2020). This new method gives us the opportunity to see objects in 3D and to understand the detail of their internal structure. Non-invasive tomodensitometry is an alternative method of analysis, which involves the development and the study of a virtual model built from the object's 3D scan. The information from the 3D scan is used to firstly provide information to reconstruct an image of the whole sword or of particular sections, also in order to complete this visual analysis, a quantitative approach of density using mathematical software is also possible. For this study, the data projections (sections) and the multiplanar reformation (MPR) (Figure 3) made it possible to characterize the different components. Multiplanar reconstructions (MPR) in particular, allow a reconstruction of sections in selected planes, linear or curved, offering the possibility of making concordant observations in the frontal and sagittal planes.

\subsection{X-Ray Fluorescence Spectroscopy (XRF)}

$\mathrm{X}$-Ray Fluorescence Spectroscopy (XRF) is an elemental analyses technique generally used on diverse materials: metals, ceramics, paintings, glasses... XRF enables the analyses of all chemical elements from Beryllium (Be) to Uranium (U) with concentrations from a few ppm to $100 \%$ and with reproducible results (Thirion-Merle 2016). The interpretation of the spectrums resulting from the XRF analyses only allows to perform a qualitative analysis by identifying the different elements and getting an idea of their relative proportions. The quantification relies on the standardisation of the device using standard reference materials allowing to determine a percentage of presence of the detected elements. XRF analysis is non-invasive and non-destructive for the object, making possible to analyse multiple points and to optimise the representativeness of the measures. 


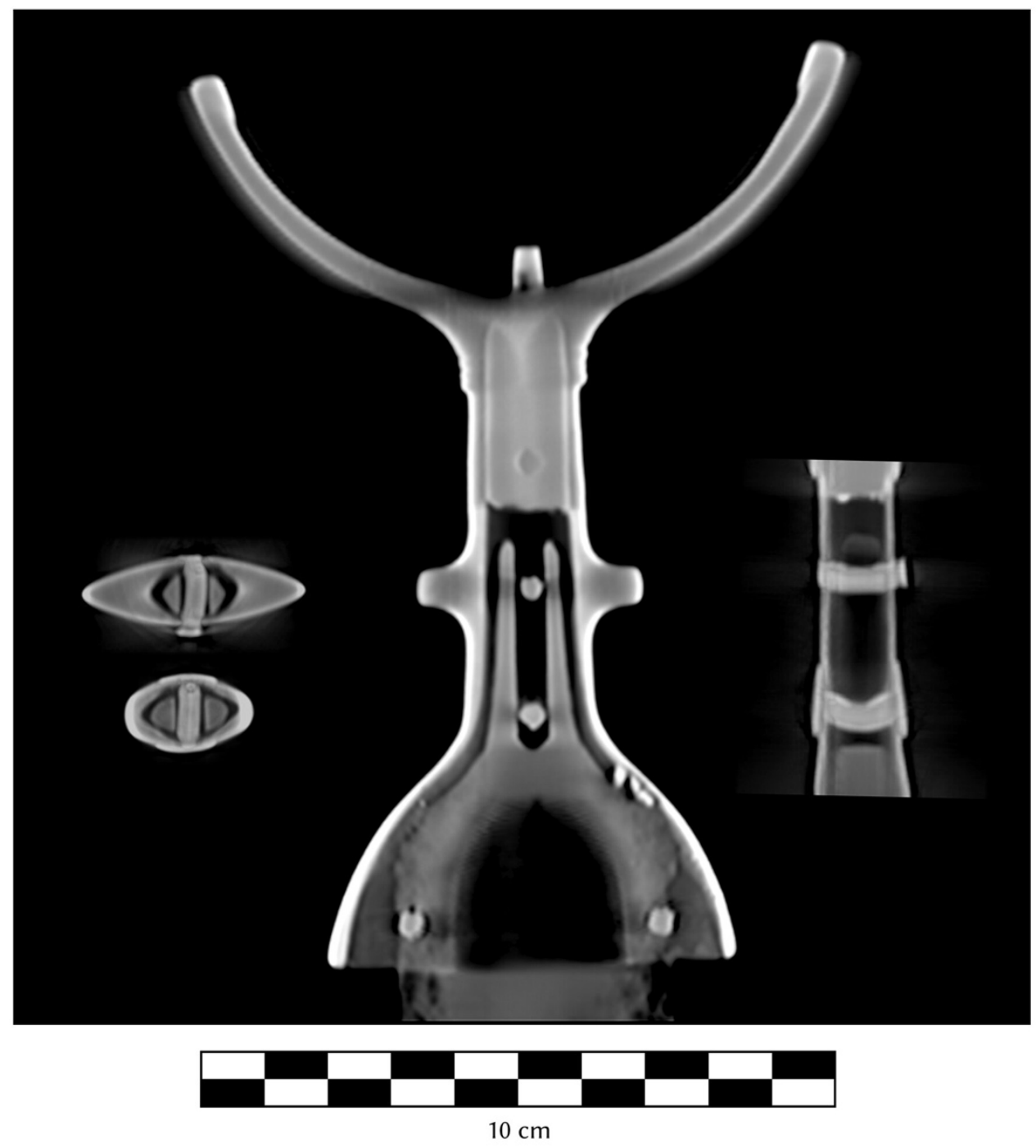

Figure 3: Different cuts on the 3D model resulting from the CT-scan depicting the organisation of the hilt, the blade tang and the rivets. C BCRX and T. Nicolas.

The device used in this study is a Bruker Tracer III-SD energy dispersive X-ray fluorescence spectrometer (EDXRF). The measuring window was $3 \times 4 \mathrm{~mm}$. The device was used with $25 \mathrm{~mA}$ power, a $25 \mathrm{kV}$ tension and a $0.141 \mathrm{keV}$ spectral resolution. Each spectre was measured during 30 seconds with a 15 seconds time-out. 16 points were measured on the sword surface: 3 on the blade, 5 on the rivets and 8 on the hilt (Figure 4). As the device was not standardised for quantitative results the analyses were limited to a qualitative determination of the elements composing the metals on the sword. $\mathrm{Ni}, \mathrm{Rh}, \mathrm{Pd}$ and $\mathrm{Ar}$ are elements belonging to the device and are therefore no indicators of analysed points composition. 


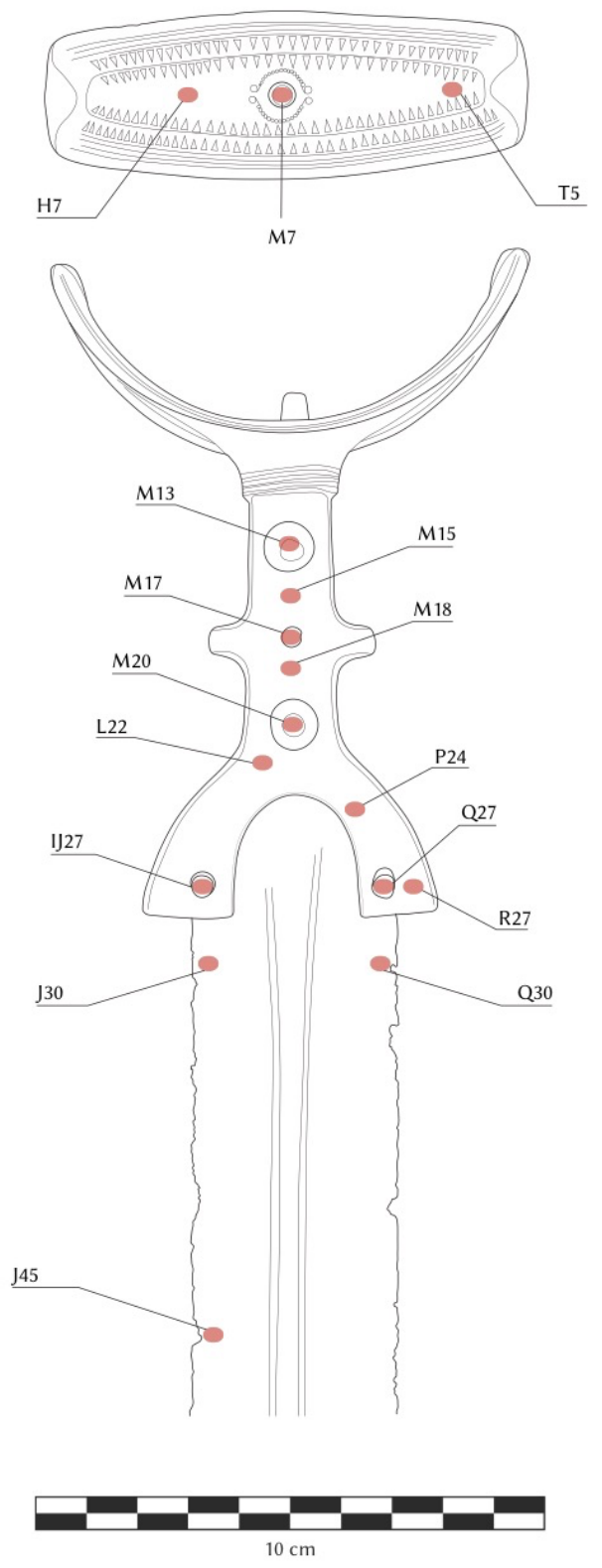

[Figure 4: Location of the points measured using X-Ray Fluorescence Spectroscopy. (C) L. Dumont.]

The main drawback of this investigation was the $12 \mathrm{~mm}^{2}$ measuring window which limited the relevance of the elemental characterisation of smaller features as the rivet heads. To overcome this problem, a relative approach was proposed by comparing the global analyse of the target (rivet head and hilt) and the analyse of the hilt body alone. Ideal analyse conditions also imply a flat area, a condition which was not always fulfilled, leading to a diminution of the signal. Results were then carefully manipulated and interpreted.

\section{Results}

\subsection{Construction of the sword}


CT-scan enables a 3D visualisation of the inside of the bronze hilt and then a precise study of the way the hilt and the iron blade were fixed one another (Figure 3). Both parts, made in different materials, can perfectly be distinguished on the slices produced thanks to the tomography. The blade presents a guard with rounded shoulders and two lateral notches in which the rivets located on the hilt guard are going through. The blade is then extended inside the hilt by a narrow and bifid tang until the middle of the grip, framing the two bottom rivets of this part. The third and upper one is taken in a massive metallic bloc which occupies the upper third of the hilt. The pommel button's nature is not certain: it could be casted with the hilt, the upper part of the block previously described sticking out by a hole in the centre of the pommel or a shaft inserted in this same metallic mass. Unfortunately, the metal thickness and density of this area does not allow to precisely see how the different parts are organised here.

It seems that the hilt and the blade are only joined together thanks to the guard rivets the one from the grips do not go through the blade tang and therefore they do not take part in the fixation of these two elements.

\subsection{Hilt, blade and rivets composition}

In the frame of the Gué-de-Velluire sword's study, XRF spectroscopy is only used as a qualitative elemental analysis of the different sword's parts through the examination of the produced spectrums (Figure 5-8). Without the possibility to perform a calibration for the analysed matrix using reference materials, the choice was made not to present any quantification of the measured elements using the device's built-in standardless calibration.

The blade mostly consists of iron ( $\mathrm{Fe}$ ) with few traces of $\mathrm{Mn}$ and $\mathrm{Cu}$ (Figure 5). The hilt and the rivets located on the grip (M13, M17, M20, see Figure 4) appear to have a similar profile (Figure 6-7). They are all made in a copper-based alloy with clear traces of $\mathrm{Sn}, \mathrm{Co}$, As and $\mathrm{Pb}$. The P24 point clearly contrasts with the other analyses performed on the hilt with strong Fe pikes that can be compared to the ones on the blade spectrum (Figure 5). This is in all probability to be related to a mispositioning of the device and an overlapping measuring window at the transition between the guard and the blade. The M7 point spectrum, corresponding to the pommel button, appears to be constantly below the other spectres (Figure 6). This is probably due to the size of this part, which is smaller than the measuring window, which leads to a signal loss for the device. These two points were excluded for computing the mean spectrum of the hilt (Figure 8). As for the rivets, the three on the grip show a composition pattern very similar to the hilt, whereas the two rivets located on the guard have a clearly different spectrum showing the presence of zinc ( $\mathrm{Zn}$ ) and a slightly higher level of iron (Fe; Figure 7). They were made using brass, contrasting with the rest of the rivets and the hilt which can be assimilated to bronze. 


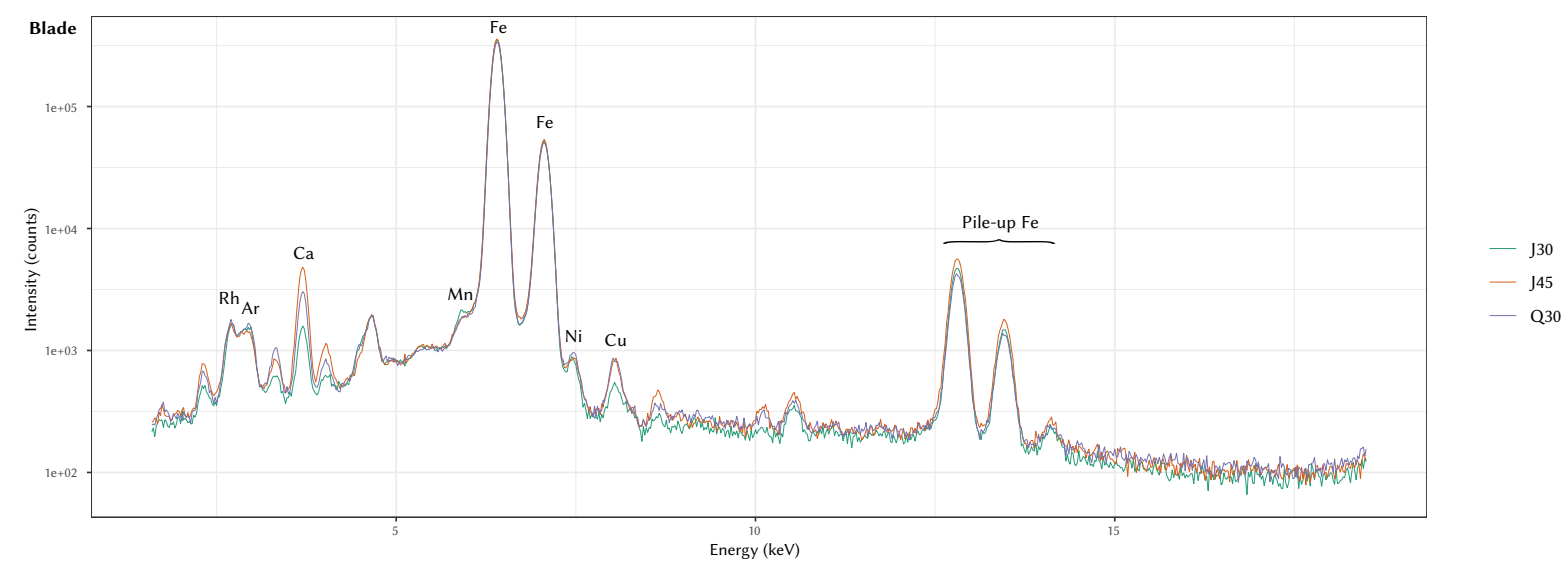

Figure 5: Spectrum resulting from the XRF measurements performed on the blade. (C) C. Pelé-Meziani and L. Dumont.

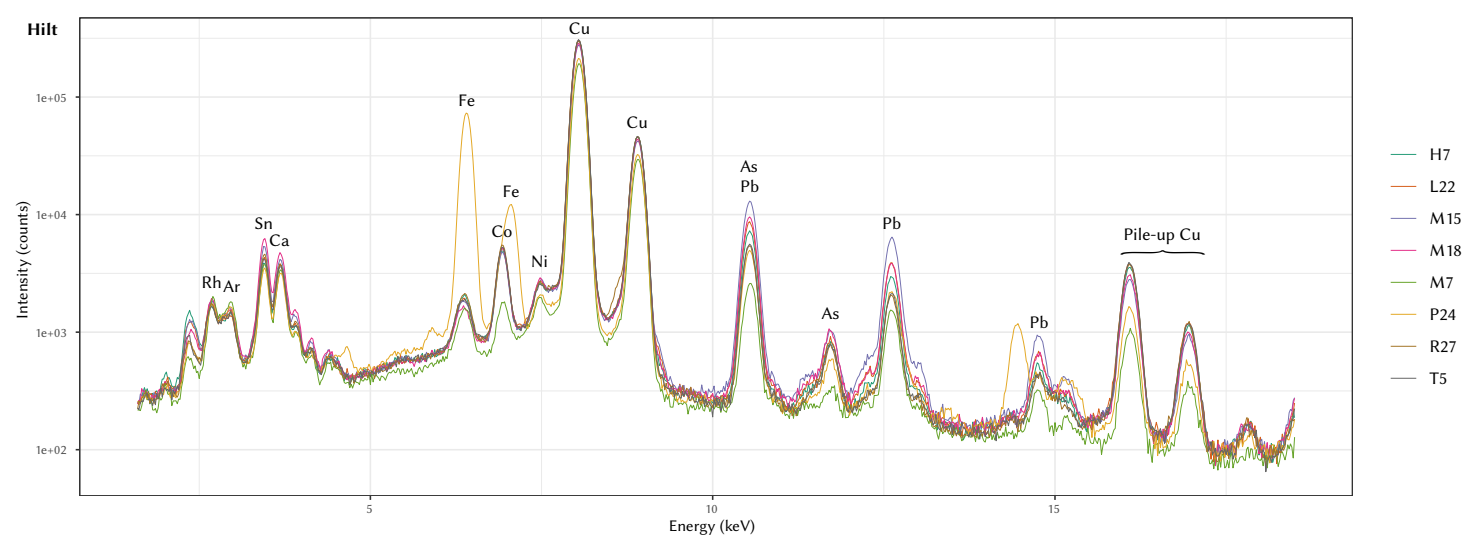

Figure 6: Spectrum resulting from the XRF measurements performed on the hilt. (C) C. Pelé-Meziani and L. Dumont.

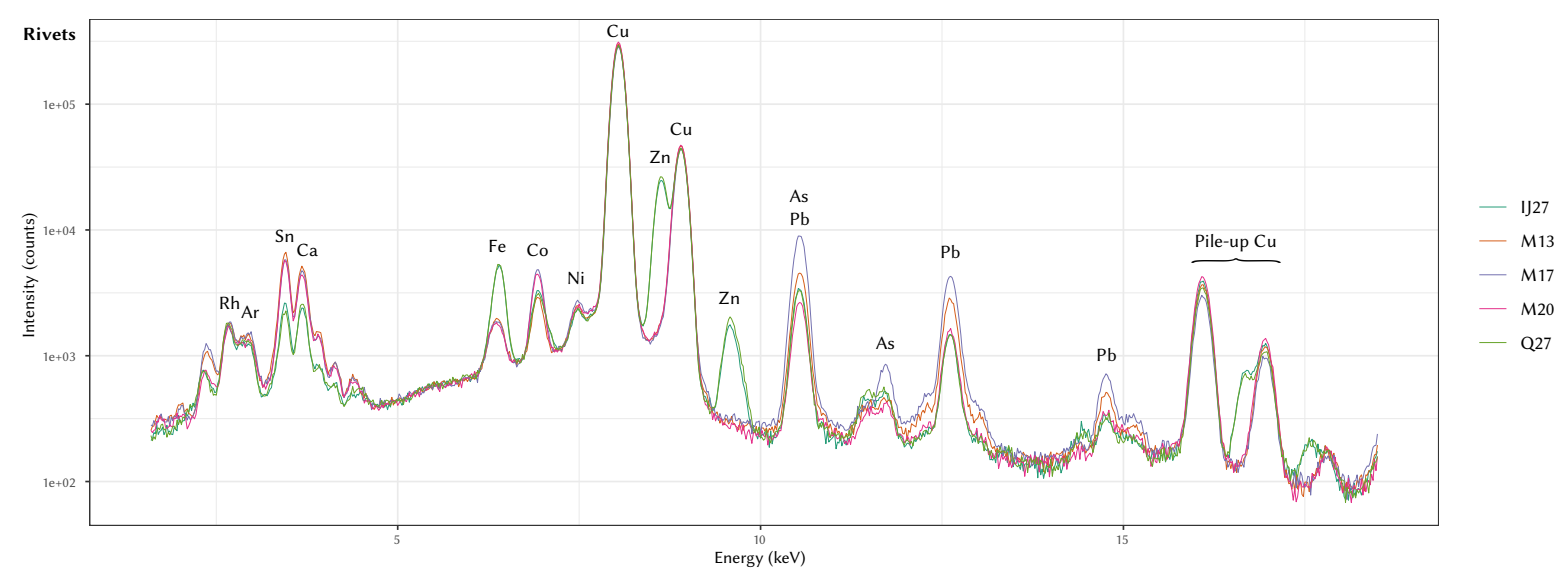

Figure 7: Spectrum resulting from the XRF measurements performed on the rivets. (C C. Pelé-Meziani and L. Dumont. 


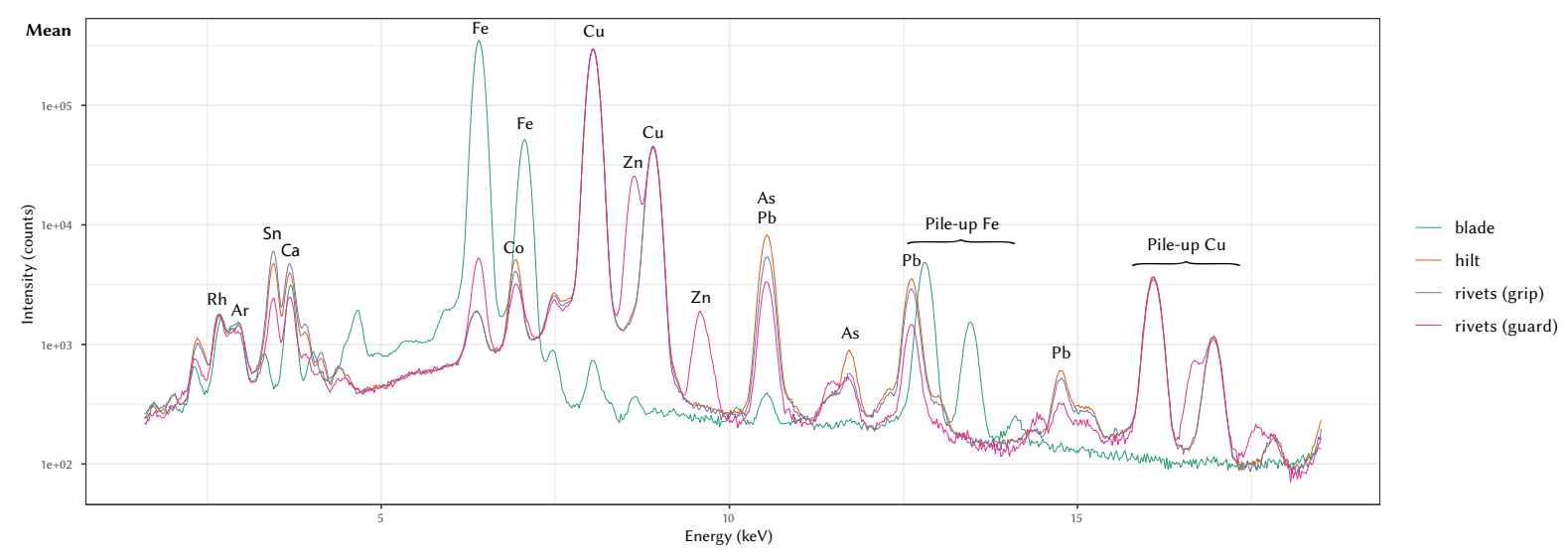

Figure 8: Mean spectrum of the different parts of the sword, excluding the M2 and P24 measuring points. (C) C. Pelé-Meziani and L. Dumont.

\section{Discussion}

\subsection{The making of a fake}

The archival documentation connected to the Rochebrune collection and the archaeometric study performed on the Gué-de-Velluire sword enable us to assess that this sword is actually a forgery or a pasticcio consisting of two different genuine archaeological artefacts that were incorporated: a bronze hilt and an iron blade that were never designed to work together. We are here dealing with an iron blade which was customised and associated with a Bronze Age hilt made in a copper-based alloy. To do so, one first had to remove the two rivets on the hilt guard. The blade tang was then hollowed out in its centre to create the bifid shape it has nowadays and the notches on the side of the blade at the transition between the tang and the cutting section were also created. By this way it was possible to insert the tang inside the hilt without removing the grip rivets. The two parts were finally fastened by adding two new brass rivets through the guard, with a different composition of the other protohistoric bronze rivets (Figures 7-8). As zinc, and therefore brass, is not known by Bronze Age craftsmen, the presence of this element associated to copper is a good marker to see the difference between modern copies or forgeries and authentic archaeological Bronze Age artefacts (Schwab et al. 2010,4). The bronze part visible inside the hollow part of the hilt just below the pommel could consist in the last element remaining of the original blade, whose tang could have been perfectly adapted to the hilt, as it is the case in the Fuglie sword (Sweden), almost identical to the Gué-de-Velluire hilt (Thrane 1968, 169).

It is impossible that the blade and the hilt were associated during the protohistoric period. Although the Rochebrune archives depict the hilt with another blade (see Figure 2), apparently made in a copperbased alloy, nothing enables us to affirm this was the original blade. The colour of the guard rivets, which appears to be much brighter than the others on the grip with a darker patina, indicates that they 
may have previously been replaced by brass rivets. The photograph may then depict an object which is also a pasticcio associating two different objects. This contrast in colour does not exist anymore since all rivets are bright and with a shiny golden colour. The original rivets may have been polished after the blade was replaced to mask the colour contrast between the original and the new ones so that the sword would look more authentic, with a better visual integration of the brass rivets.

Using the available information, it is unfortunately not possible to find out the provenance of the blade and the hilt used to create the Gué-de-Velluire sword. The hilt shape finds parallels in two Scandinavian swords, one coming from Fuglie (Sweden) and the other from Hundborg (Denmark; Halbert 1954). Another sword dredged in the Seine river in Évry (Essonne, France) should also be mentioned considering the likeness of the hilt and especially the shape of the grip (Guillaumet et al. 1999, 64). A dating to the $10^{\text {th }}$ or $9^{\text {th }}$ century BC can be proposed based on these parallels and their shape.

The blade's case is much more complicated. If the hilt has almost identical comparisons in southern Scandinavia, the blade's features are quite unique. Whereas La Tène blades are usually smooth, the grooves on the Gué-de-Velluire can be compared to the sword coming from the Donges swamp (LoireAtlantique, France), dating back to the Hallstatt period, more precisely to the second half of the $7^{\text {th }}$ or the first half of the $6^{\text {th }}$ century BC (Verger 1999; Lejars 2014, 48), or to the iron blade from Trentemoult (Rezé, Loire-Atlantique, France), which dates back to the La Tène B1 period, corresponding to the first half of the $4^{\text {th }}$ century BC (Lejars 1999; Lejars 2014, 33). This last sword presents thin grooves framing the narrow blade's central bulge in a very similar way as the grooves on the Gué-de-Velluire sword's blade. The diamond-shaped section of the tang (see Figure 4) remains however unparalleled so far and may be the result of a modification of this part when the blade was associated with the bronze hilt. This iron blade could then have been produced in the late Hallstatt or Early La Tène period.

The allocation of this bronze hilt and this iron blade to Le Gué-de-Velluire is very unlikely considering it was sold several times before it entered the Rochebrune collection and afterwards the Dobrée Museum (see 2.2). Considering the attachment of count de Rochebrune to the Vendée region, the hypothesis of a spurious provenance deliberately attributed to the sword in order to highlight the archaeological wealth of this territory, and especially the Gué-de-Velluire municipality where Raoul de Rochebrune excavated, is currently the most likely explanation for the publication of this counterfeit as an authentic archaeological object (Mortillet 1913; Rochebrune 1917).

\subsection{Copies and forged Bronze Age swords}

Many Bronze Age sword copies and forgeries are known in museum collections. They can be classified in different categories. Some museums made copies themselves in plaster or in metal in order to complete their own collection, to exchange with other museums, to sell them or for teaching purposes, like it was the case in the Musée d'Archéologie Nationale (Saint-Germain-en-Laye, France) in the $19^{\text {th }}$ and at the beginning of the $20^{\text {th }}$ century (Dumont, Simon-Millot 2020). 
Some counterfeits were nevertheless produced to serve less noble aims, such as financial gain. For example, it seems to be the case of a Bronze Age solid-hilted sword conserved in the city museum of Ghent (Belgium) and said to come from the surroundings of the municipality: it is actually a copy of a sword found in Germany which was artificially corroded and on which damages were faked on the blade. It is likely that the aspect of the copy was altered to make it look like an authentic Bronze Age sword, possibly at the moment of its sale in Brussels in 1933: the invention of a local provenance enabled to make it look less suspicious and sell it more easily (Dumont et al. 2020).

Finally, there are some fakes we could describe as ideological. The Oedt sword (Nordrhein-Westfalen, Germany) for example fits in this category. It is composed of an authentic Bronze Age blade on which a modern brass and a fire-gilded hilt was added. This pasticcio was produced before 1947, probably in the National-Socialist context of Germany (Schwab et al. 2010; Joachim, Willer 2013). Production of counterfeits may during this period have been linked to ideological purposes, here to highlight the skill and the power of populations who once lived in the current German borders. As it was mentioned previously ( $c f .2 .2$ and 5.1), the Gué-de-Velluire sword may fit in this kind of forgeries. Although, it has of course nothing to do with Nazi Germany, the idea to highlight the archaeological wealth of a territory or of an archaeological site can be classified under the same falsification approach as the Oedt sword. Unfortunately, it is not an easy task to see the difference between these fakes and actual archaeological artefacts. A simple surface observation is not always sufficient, either because of an artificial patina or, as in the case of the Gué-de-Velluire sword, which consists of a combination of genuine archaeological pieces. The combination of imaging techniques and elemental analyses appears to be a suitable solution for checking the authenticity of a suspicious artefact. Imaging techniques such as radiography or tomography enable the researchers to identify the use of techniques unknown or very uncommon in the Bronze Age, such as fire-gilding for the already mentioned Oedt sword (Schwab et al. 2010). Many copies were also made by casting the hilt and the blade as one single piece with a very little degree of porosity, which almost never occurs in the Bronze Age, where hilts and blades are usually made separately with a porosity visible using X-rays. The sword at the Ghent Museum is a typical example of a fake sword: it is casted in one piece without any porosity in the hilt area (Dumont et al. 2020). Elemental analysis can also be helpful by detecting the presence of a high percentage of zinc, which is not known in the Bronze Age (Schwab et al. 2010, 4). Its addition to the alloy of these objects makes it possible to detect copies or forgeries. The absence of zinc is however not sufficient to prove the authenticity of an object. It would be interesting to perform elemental analyses on a large number of copies, fakes and forgeries in order to establish a framework to be able to see the difference between archaeological and modern compositions.

\section{Conclusion}


CT-scan and XRF analyses enabled a better understanding of the biography of the so-called Gué-deVelluire sword and to answer questions that were raised by the archival documentation depicting it with a different blade then the one which is currently associated with the bronze hilt. It is now possible to asses this object as a modern pasticcio made after it was bought by R. de Rochebrune in 1904, and before its publication by A. de Mortillet in 1913. It consists of a combination of a Bronze Age bronze hilt and a Hallstatt or La Tène iron blade. Both appear to be real archaeological artefacts that were however never designed to function together as a sword. In order that they could be fixed together, the blade tang was hollowed out to insert it in the hilt without removing the grip rivets. The two original rivets on the guard were however removed and replaced by modern brass rivets. It is not impossible that the original rivets at the upper part of the hilt were polished in order to provide a better visual integration to the new shiny golden rivets. Contrary to these elements containing a significant amount of zinc, all the other parts of the hilt were made using a classic Bronze Age copper-based alloy.

Unfortunately, it is not possible to determine the actual provenance of the hilt and the blade. The Rochebrune collection contains several suspicious pieces said to come from Le Gué-de-Velluire. This sheds light on the $19^{\text {th }}$ and early $20^{\text {th }}$ century collectors' practices, who did not seem interested in the real provenance of the object they bought or about their authenticity. Many fake archaeological artefacts were made in these times. Among them, swords occupy an important place. It is indeed a sought-after object for its aesthetics and the power symbols attached to it, leading to the production of counterfeits and forgeries which were meant to be sold or to be used as a proof of the archaeological wealth of a territory. Archaeometric studies performed on the Gué-de-Velluire sword made it possible to give an answer to the question of its authenticity but also to document the collectors' practices which are at the origin of many spurious objects in today's public collections.

\section{Acknowledgements}

This study and the analyses were only possible thanks to the financial and material support of the Grand Patrimoine de Loire-Atlantique services through the Dobrée Museum and the Arc'Antique laboratory, as well as Ghent University by the BOF funded project "Production and diffusion of Bronze Age solidhilted swords in Western Europe". The authors are also very grateful to Thierry Lejars (senior researcher, CNRS) for his help with the study of the iron blade of the so-called Gué-de-Velluire sword.

\section{Bibliography}

Barthet, L., 2012. Retouches, trucages et remontages : la singulière fortune des épées de la collection Rochebrune. Bulletin de la Société archéologique et historique de Nantes et de Loire-Atlantique 147, $15-31$. 
Coutil, L., 1928. Poignards, rapières et épées de l'âge du Bronze. L'Homme préhistorique 1928, 1-2, $11-64$.

Dumont, L., De Kock, T., Lycke, S., Tack, P., Vandenabeele, P., 2020. The true and the fake: archaeometric investigations on two Bronze Age solid-hilted swords from East-Flanders (Belgium). Lunula. Archaeologia protohistorica 28, 79-87.

Dumont, L., Simon-Millot, R., 2020. Un exemple de moulage au Musée d'Archéologie Nationale de Saint-Germain-en-Laye : l'épée perdue de Cléry-Saint-André (Loiret). Bulletin de l'APRAB 18, 14-21.

Espérandieu, É., 1888. Épigraphie romaine du Poitou et de la Saintonge. E. Lacuve, Melle.

Fillon, B., Rochebrune, O. de, 1863. Poitou et Vendée : études historiques et artistiques. L. Clouzot, Niort.

Gomez, J., Mohen, J.-P., 1981. Les plus vieux objets en fer de France, in: Haefner, H. (Ed.), Frühes Eisen in Europa. Presented at the Actes du $3^{\mathrm{e}}$ symposium des Comités pour la sidérurgie ancienne de l’UISPP, Peter Meili, Schaffhausen, pp. 53-56.

Gomez de Soto, J., Kerouanton, I., 2009. Les premiers objets en fer en France, à l'âge du Bronze, in: De l'âge du Bronze à l'âge du Fer en France et en Europe occidentale (Xe - VIIe siècle av. J.-C.)., Supplément à la Revue archéologique de l'Est. Presented at the Actes du XXXe colloque international de l'A.F.E.A.F., co-organisé avec l'A.P.R.A.B., Société archéologique de 1’Est, Dijon, pp. 501-506.

Halbert, L., 1954. Un groupe particulier parmi les épées de l'âge du Bronze récent. Meddelanden från Lunds universitets historiska museum 6, 413-426.

Joachim, H.-E., Willer, F., 2013. Alte Waffe mit neuem Griff. Das vermeintlich mittelbronzezeitliche Schwert von Oedt. Bonner Jahrbücher 213, 9-16. https://doi.org/10.11588/bjb.2013.0.43966

Lejars, T., 1999. Épée à fourreau décoré, in: Santrot, M.-H., Meuret, J.-C. (Eds.), Nos ancêtres les Gaulois aux marges de l’Armorique. Musée Dobrée, Nantes, pp. 117.

Lejars, T., 2014. Les armes gauloises du Pont-de-L'Ouen (dép. Loire-Atlantique / F) : une découverte inattendue. Jahrbuch des Römisch-Germanischen Zentralmuseums Mainz 61.1, 19-55. https://doi.org/10.11588/jrgzm.2014.1.72367

Miketta, F., 2017a. Die ältesten Eisenartefakte Mitteleuropas, in: Mirossayová, E., Pare, C., StegmannRajtár, S. (Eds.), Das nördliche Karpatenbecken in der Hallstattzeit. Wirtschaft, Handel und Kommunikation in früheisenzeitlichen Gesellschaften zwischen Ostalpen und Westpannonien. Archaeolingua, Budapest, pp. 143-172.

Miketta, F., 2017b. Die bronzezeitliche Eisenartefakte aus Mittel- und Westeuropa. Chronologische, typologische und chorologische Untersuchungen, Universitätsforschungen zur prähistorischen Archäologie. Verlag Dr. Rudolf Habelt, Bonn. 
Milcent, P.-Y., 2004. Le premier âge du Fer en France centrale, Mémoire de la Société préhistorique française. Société préhistorique française, Paris.

Mortillet, A. de, 1913. Note sur une épée en fer trouvée en Vendée. Revue Anthropologique 23, 275 280.

Mortillet, A. de, 1909. Épée en bronze trouvée dans la Loire. L’Homme préhistorique 7.8, 230-232.

Mödlinger, M., 2008. Micro-x-ray computer tomography in archaeology: analyses of a Bronze Age sword. Insight 50.6, 323-325. https://doi.org/10.1784/insi.2008.50.6.323

Müller-Karpe, H., 1961. Die Vollgriffschwerter der Urnenfelderzeit aus Bayern, Münchner Beiträge zur Vor- und Frühgeschichte. C. H. Beck, Munich.

Mustra, M., Delac, K., Grgić, M., 2008. Overview of the DICOM Standard, in: Grgić, M., Grgić, S. (Eds.), ELMAR 2008, 50th International Symposium ELMAR, Croatian Society Electronics in Marine, Zadar, pp. 39-44.

Parpoil, C., 2007. Petrimonalisation d'une collection : le legs de la collection Raoul de Rochebrune au musée Dobrée (PhD thesis). Université Paul Valéry - Montpellier III, Montpellier.

Pautreau, J.-P., 1984. Le passage de l'âge du Bronze à l'âge du Fer en Poitou, in: Transition Bronze final Hallstatt ancien : problèmes chronologiques et culturels. Presented at the Actes du 109e congrès national des sociétés savantes, CTHS, Paris, pp. 229-249.

Rochebrune, O. de, 1880. Collections de Terre-Neuve appartenant à Octave de Rochebrune. Les armes depuis l'âge celtique jusqu'au XVIIIe siècle. L. Clouzot, Niort.

Rochebrune, R. de, 1911. Les armes offensives à travers les âges jusqu'au XVI siècle. Revue du BasPoitou, 81.96, 153-164.

Rochebrune, R. de, 1917. Collection du comte Raoul de Rochebrune, Château de la Court, Saint-Cyren-Talmondais (Vendée), S. Pacteau, Luçon.

Schwab, R., Willer, F., Meinel, D., Schmauder, M., Pernicka, E., 2010. The Oedt sword: A note on brass and fire-gilding in the European Bronze Age. Historical Metallurgy 44.1, 1-9.

Stelzner, J., Gauß, F., Schuetz, F., 2016. X-ray computed tomography for non-destructive analysis of early Medieval swords. Studies in Conservation 61.2, 86-101.

https://doi.org/10.1179/2047058414Y.0000000157

Thirion-Merle, V., 2014. Spectrométrie de fluorescence X, in: Dillmann, P., Bellot-Gurlet, L. (Eds.), Circulation et provenance des matériaux dans les sociétés anciennes. Éditions des archives contemporaines, Paris, pp. 291-297. 
Thrane, H., 1968. Eingeführte Bronzeschwerter aus Dänemarks jüngerer Bronzezeit. Acta Archaeologica 39, 143-218.

Verger, S., 1999. Épée à antennes, in: Santrot, M.-H., Meuret, J.-C. (Eds.), Nos ancêtres les Gaulois aux marges de l'Armorique. Musée Dobrée, Nantes, pp. 114. 